Jurnal Ilmiah ESAI Volume 13, No. 1, Januari 2019

p-ISSN 1978-6034 e-ISSN 2580-4944

Understanding and Concern to Implementation of Green Accounting: A Case Study of SME Tempe Tofu in Bandar Lampung City

\title{
Pemahaman dan Kepedulian Penerapan Green Accounting: Studi Kasus UKM Tahu Tempe di Kota Bandar Lampung
}

\section{Destia Pentiana ${ }^{1)}$}

1) Program Studi Akuntansi Perpajakan, Jurusan Ekonomi dan Bisnis Politeknik Negeri Lampung email : destiapentiana@polinela.ac.id

\begin{abstract}
The general objective of this study is to find out whether: 1) the SMEs of tofu and tempe in Bandar Lampung city have knowledge of the concept of green accounting 2) the SMEs of tofu and tempe in Bandar Lampung city care about the environment. The type of data used in this study is primary data, namely by interviewing and distributing questionnaires to the businessmen of tofu and tempe in Bandar Lampung city. Based on the results of the questionnaire, it was found that the understanding of the perpetrators of SMEs of tofu and tempe in Bandar Lampung city is still low because the preference of the interests of the actors of SMEs of tofu and tempe is still focused on operating profits not on product quality and environmental quality. The lack of awareness of environmental impacts that can affect the sustainability of its business is a factor that causes the low level of understanding. In terms of knowledge of the environmental costs, SMEs is also identified low. This is because the business actors are unable to identify what constitutes the components of environmental costs which also become a factor that causes low understanding of the SMEs.
\end{abstract}

Keywords: Green Accounting, Environmental Costs, SMEs.

\section{Pendahuluan}

Salah satu sektor industri yang merupakan pilar penyangga perekonomian di Indonesia adalah sektor Usaha Kecil dan Menengah (UKM), peran UKM sendiri terlihat dari jumlah unit usaha dan daya serap tenaga kerja oleh UKM yang cukup signifikan. Berdasarkan data Dinas Koperasi dan UMKM menyebutkan, UMKM sektor perdagangan memiliki rata-rata omzet sebesar Rp41,6 juta per tahun, sedangkan sektor jasa memiliki omzet rata-rata sedikitnya Rp51 juta hingga Rp53,4 juta per tahun. Sementara UMKM sektor industri yang didominasi oleh industri tahu tempe, keripik, kerajinan sulam usus, serta industri perikanan seperti ikan teri dan ikan asin memiliki omzet dengan kisaran antara Rp74 juta hingga Rp86 juta per tahun.

Besarnya omzet pendapatan dari sektor industri tahu tempe sayangnya tidak diikuti dengan kepedulian pelaku usaha tersebut akan kelestarian lingkungan, rendahnya kesadaran sektor UKM dalam kepedulian lingkungan membawa pengaruh buruk bagi kualitas lingkungan. Kenyataanya UKM menjalankan usaha tanpa melihat dari sisi ekologis dan hanya berorientasi pada profit saja (Purwaningsih, 2008). Berdasarkan data industri pengolahan yang berkontribusi paling tinggi di Kota Bandar Lampung pada tahun 
2016 yaitu industri pengolahan makanan dan minuman sebesar Rp 6.287.775,5 atau sebesar $20,03 \%$. Salah satu industri pengolahan yang banyak berkembang di Kota Bandar Lampung salah satunya adalah UKM tahu tempe, biasanya industri ini masih bersifat kekeluargaan dan pengelolaannya masih belum memperhatikan kondisi lingkungan sehingga usaha ini menyumbang limbah cair yang cukup besar. Berdasarkan data ternyata limbah cair yang berasal dari proses perebusan dan perendaman kedelai tersebut mempunyai suhu, TDS, TSS, BOD, COD serta amoniak bebas yang dihasilkan melebihi standart baku mutu limbah cair, sehingga dapat mencemari lingkungan (Wiryani, 2007).

Kesadaran masyarakat atas lingkungan memunculkan gerakan peduli lingkungan (green movement) yang mendasari munculnya green accounting sebagai bentuk konsekuensi industri. Green accounting merupakan jenis akuntansi yang mencoba memasukkan faktor biaya lingkungan kedalam hasil keuangan usaha (Kartikasari, 2012). Perilaku akuntan dengan memasukan biaya lingkungan dalam komponen biaya-biaya perusahaan akan menghasilkan penilaian kuantitatif tentang biaya dan efek perlindungan lingkungan perusahaan. Green accounting juga secara khusus membahas tentang identifikasi, pengukuran dan alokasi biaya lingkungan, mengintegrasikan biaya lingkungan ke dalam bisnis dan mengidentifikasi kewajiban terhadap lingkungan.

Kehadiran green accounting sendiri bertujuan sebagai alat manajemen lingkungan untuk menilai keefektifan kegiatan konservasi berdasarkan ringkasan dan klasifikasi biaya konservasi lingkungan (Pramanik et al. 2008). Namun untuk menerapkan green accounting di Indonesia diperlukan adanya proses akulturasi sikap dan perilaku ekonomi berbasis ekologi yang tidak serta merta dapat berlaku dalam suatu wilayah akuntansi sosial, atau memberi efek spektrum yang begitu luas pada bidang lain (Jafar dan Kartikasari, 2012). Proses akulturasi tersebut membutuhkan kesiapan pengetahuan, teknologi, dan terutama kesadaran konvensional dalam praktik bisnis dan yang pasti memerlukan waktu yang tidak singkat dalam penerapannya.

Penelitian ini dilakukan pada UKM tahu tempe di kota Bandar Lampung. Jenis usaha ini dipilih karena jenis usaha ini memberi pengaruh yang cukup besar dalam pelestarian alam, karena para pemilik usaha tahu tempe sering membuang limbah secara sembarangan.Terkait dengan hal tersebut, penelitian ini membahas sejauh mana pelaku bisnis sebagai salah satu unsur utama peduli akan lingkungan dan mengetahui serta memiliki pengetahuan mengenai green accounting.

Berdasarkan perumusan masalah maka penelitian ini dilakukan dengan tujuan untuk mengetahui: (1) Apakah pelaku UKM tahu tempe di kota Bandar Lampung memiliki pengetahuan mengenai konsep green accounting? (2) Apakah pelaku UKM tahu tempe di kota Bandar Lampung peduli dengan lingkungan? 


\section{Kajian Literatur}

\section{Green Accounting}

Akuntansi merupakan suatu ilmu yang dipengaruhi dan mempengaruhi lingkungannya. Eksistensinya tidak bebas nilai terhadap perkembangan masa. Metode-metode pembukuan juga terus berkembang mengikuti kompleksitas bisnis yang semakin tinggi. Ketika kepedulian terhadap lingkungan mulai mendapat perhatian masyarakat, akuntansi berbenah diri agar siap menginternalisasi berbagai eksternalitas. Belkoui dan Ronald (1991) dalam Idris (2012) menjelaskan bahwa budaya merupakan faktor utama yang mempengaruhi perkembangan struktur bisnis dan lingkungan sosial, yang pada akhirnya akan mempengaruhi akuntansi. Konsekuensi dari wacana akuntansi sosial dan lingkungan ini pada akhirnya memunculkan konsep Socio Economic Environmental Accounting (SEEC) yang sebenarnya merupakan penjelasan singkat pengertian Triple Bottom Line, yaitu pelaporan akuntansi ke publik tidak saja mencakup kinerja ekonomi tetapi juga kinerja lingkungan dan sosialnya.

Green accounting yang terkadang dikenal sebagai Environmental Accounting menurut Ikhsan (2008) adalah istilah yang berkaitan dengan dimasukkannya biaya lingkungan (environmental costs) ke dalam praktek akuntansi perusahaan atau lembaga pemerintah. Akuntansi lingkungan (Green Accounting) merupakan sarana untuk melaporkan operasional suatu lembaga (negara/kota/perusahaan/organisasi) yang dikaitkan dengan lingkungan. Tujuannya adalah memberikan informasi mengenai kinerja operasional perusahaan yang berbasis pada perlindungan dan kepedulian terhadap lingkungan.

Perusahaan yang tergolong UKM, biasanya hanya mementingkan profit dan tidak peduli pada lingkungan (Martusa, 2009). Oleh karena itu, pemahaman mengenai akuntansi lingkungan (green accounting) menjadi sangat penting bagi pelaku usaha di UKM karena ketika para pemilik UKM mengerti mengenai akuntansi lingkungan dan peduli terhadap lingkungan tempat mereka berusaha maka upaya mengurangi permasalahanpermasalahan lingkungan yang dihadapi saat ini akan terwujud.

Penelitian Teoh dan Thong (1986) dalam Musyarofah (2013) menyatakan bahwa suatu organisasi dapat dikategorikan ikut andil dalam menjaga lingkungan hidup jika memiliki perhatian terhadap lingkungan hidup (Environmental awareness) itu sendiri, yang selanjutnya diikuti dengan keterlibatan organisasi tersebut terhadap permasalahan lingkungan (Environmental Involvement). Hal ini perlu diikuti dengan pelaporan lingkungan (Environmental Reporting), terutama kinerja organisasi dalam mengatasi dampak kegiatan organisasi terhadap lingkungan, yang kemudian disempurnakan dengan kegiatan audit lingkungan (Environmental Auditing) untuk mengukur dan mengevaluasi kinerja organisasi. Oleh karena itu dapat disimpulkan setidaknya diperlukan empat faktor dalam hal tanggung jawab organisasi terhadap lingkungan adalah kepedulian lingkungan, keterlibatan lingkungan, laporan lingkungan, dan audit lingkungan. 
Menurut Kwarto (2010) Beberapa pertimbangan bagi perusahaan untuk menerapkan akuntansi lingkungan sebagai bagian dari sistem akuntansi perusahaan yaitu: (1) Memungkinkan mengurangi dan menghilangkan biaya lingkungan. Meningkatkan kinerja lingkungan perusahaan yang mungkin memiliki dampak negatif pada manusia, kesehatan dan keberhasilan bisnis perusahaan. (3) Diharapkan menghasilkan biaya atau harga yang lebih akurat terhadap produk dari proses lingkungan yang diinginkan dan memungkinkan untuk memenuhi kebutuhan pelanggan yang mengharapkan produk yang lebih baik/ jasa lingkungan.

\section{Biaya Lingkungan}

Biaya lingkungan merupakan dampak yang timbul dari sisi keuangan maupun non keuangan yang harus dipikul sebagai akibat dari kegiatan yang mempengaruhi kualitas lingkungan (Ikhsan, 2008). Biaya lingkungan yang terjadi dalam perusahaan merupakan salah satu biaya overhead pabrik yang sulit sekali untuk diidentifikasi secara langsung dikarenakan biaya-biaya tersebut seringkali tersembunyi dalam pusat biaya dan tidak ada bukti pencatatan ataupun pelaporan yang sangat jelas terkait dengan biaya-biaya lingkungan (Ikhsan, 2008).

Aktivitas-aktivitas dalam pelaksanaan green accounting tentunya mengeluarkan biaya. Aktivitas tersebut merupakan biaya yang harus dibebankan oleh perusahaan yang timbul bersamaan dengan penyediaan barang dan jasa kepada konsumen. Dengan beban yang telah dialokasikan diharapkan akan membentuk lingkungan yang sehat dan terjaga kelestariannya. Kinerja lingkungan merupakan salah satu pengukuran penting dalam menunjang keberhasilan perusahaan. Beberapa alasan yang dapat mendukung pelaksanaan akuntansi lingkungan antara lain (Fasua, 2011): 1) Biaya lingkungan secara signifikan dapat dikurangi atau dihilangkan sebagai hasil dari keputusan bisnis, mulai dari perubahan dalam operasional dan pemeliharaan untuk diinvestasikan dalam proses yang berteknologi hijau serta untuk perancangan kembali produk yang dihasilkan; 2) Biaya lingkungan jika tidak mendapatkan perhatian khusus akan menjadi tidak jelas dan masuk dalam akun overhead atau bahkan akan diabaikan; 3) Banyak perusahaan telah menemukan bahwa biaya lingkungan dapat diimbangi dengan menghasilkan pendapatan melalui penjualan limbah sebagai suatu produk.; 4) Pengelolaan biaya lingkungan yang lebih baik dapat menghasilkan perbaikan kinerja lingkungan dan memberikan manfaat yang signifikan bagi kesehatan manusia serta keberhasilan perusahaan; 5) Memahami biaya lingkungan dan kinerja proses dan produk dapat mendorong penetapan biaya dan harga produk lebih akurat dan dapat membantu perusahaan dalam mendesain proses produksi, barang dan jasa yang lebih ramah lingkungan untuk masa depan; 6) Perusahaan mempunyai keunggulan kompetitif yang didapat dari proses, barang, dan jasa yang bersifat ramah lingkungan; 7) Akuntansi untuk biaya lingkungan dan kinerja lingkungan dapat mendukung perkembangan perusahaan dan operasi dari sistem manajemen lingkungan secara keseluruhan; dan 8) Pengungkapan 
biaya lingkungan akan meningkatkan nilai dari pemegang saham karena kepedulian perusahaan terhadap pelestarian lingkungan.

Penelitian yang terkait dengan green accounting merupakan topik baru dalam riset akuntansi manajemen. Oleh karena itu, penelitian-penelitian yang terkait dengan green accounting masing jarang. Penelitian yang dilakukan Christyawan (2014) meneliti kepedulian dan pengetahuan pelaku usaha mengenai green accounting yang dilakukan pada usaha tahu di kota Salatiga, dari penelitian diperoleh bahwa pelaku usaha mengaharapkan biaya yang rendah untuk dapat melakukan kegiatan produksi. Pelaku bisnis peduli terhadap lingkungan, namun tidak mengetahui komponen-komponen biaya lingkungan dan juga cara memasukkan biaya lingkungan ke dalam biaya usaha. Sedangkan penelitian yang dilakukan oleh Arizona dan Suarjana (2017) yang juga meneliti kepedulian dan pengetahuan pelaku bisnis mengenai green accounting, penelitian dilakukan pada jenis usaha rumah makan yang terdapat di kota Denpasar. Kesimpulan dari penelitian diperoleh bahwa pelaku usaha rumah makan di kota Denpasar lebih mementingkan kualitas, laba dan omzet dalam kegiatan usahanya daripada untuk penanganan limbah. Hal ini terjadi karena memang UKM biasanya lebih berorientasi pada profit (profit oriented) sehingga untuk memperoleh laba dan omzet yang tinggi maka mereka menjaga kualitas produknya, sehingga untuk pengeluaran biaya lingkungan seringkali diabaikan.

\section{Metode Penelitian}

Penelitian ini dilakukan pada UKM tahu tempe yang berada di kota Bandar Lampung yaitu wilayah Gunung Sulah. Jenis data yang digunakan dalam penelitian ini adalah data primer, yaitu dengan wawancara dan pembagian kuesioner kepada pelaku bisnis tahu tempe. Fokus penelitian ini adalah mengetahui tingkat pengetahuan dan kepedulian pelaku bisnis mengenai biaya lingkungan dan green accounting di lingkungan usahanya. Kuesioner yang digunakan dikembangkan dari penelitian yang dilakukan oleh Christyawan (2014). Data sekunder data dari dinas koperasi dan UMKM kota Bandar Lampung dan sumber referensi yang relevan mengenai green accounting. Sampel yang diperoleh dari penyebaran kuesioner sebanyak 30 kuesioner.

Kategori untuk mengetahui pengetahuan dan kepedulian pelaku bisnis menurut Arikunto (2006) dibagi dalam 3 kategori, yaitu; 1) Baik : Bila subjek mampu menjawab dengan benar $76 \%$ - 100\% dari seluruh pertanyaan; 2) Cukup : Bila subjek mampu menjawab dengan benar $56 \%-75 \%$ dari seluruh pertanyaan; dan 3) Kurang: Bila subjek mampu menjawab dengan benar 40\% - 55\% dari seluruh pertanyaan.

Dalam penelitian ini, subjek dikatakan benar apabila menyatakan tahu dan peduli dengan mengisi kuesioner diatas poin 4 atau netral ke atas. Variabel dalam penelitian ini menggunakan distribusi frekuensi, dengan distribusi frekuensi ini seseorang bisa dengan mudah melihat bagaimana sekumpulan data mengelompok dan bagaimana kira-kira model 
populasi data dapat diperoleh. Variabel yang digunakan dalam penelitian ini:

Preferensi kepentingan. Pengukuran dengan memberikan kode untuk mengubah persepsi/opini secara kualitatif ke dalam suatu urutan kuantitatif. Skala pengukuran yang digunakan tersebut bertujuan untuk mengukur persepsi responden mengenai tingkat kepentingan dalam usaha. Masing-masing indikator akan diukur dengan menggunakan skala pengukuran yang akan diberi nilai antara 1 sampai 6 yang menunjukkan tingkatan dari masing-masing indikator. Dengan deskripsi sebagai berikut, nilai "1" akan diberikan jika responden menjawab "sangat penting", nilai "2" diberikan jika responden menjawab "penting", nilai "3" diberikan jika responden menjawab "cukup penting", nilai "4" diberikan jika responden menjawab "kurang penting" nilai "5" diberikan jika responden menjawab "tidak penting". Dan nilai " 6 " jika responden menjawab "sangat tidak penting."

a. Kepedulian lingkungan. Variabel ini menunjukkan nilai dasar dan sikap dari pelaku usaha dalam memperhatikan dan bertindak proaktif terhadap kondisi atau keadaan di sekitar lingkungan usaha. Menunjukkan sikap keberpihakan untuk melibatkan diri dalam persoalan lingkungan dan perlakuan terhadap limbah usaha.

b. Kesadaran biaya lingkungan. Variabel ini menunjukkan pengertian yang mendalam pada diri pelaku usaha yang terwujud dalam pemikiran sikap dan tingkah laku dan tanggung jawab pelaku usaha mengenai biaya lingkungan yang terjadi dalam usahanya.

c. Pengetahuan biaya usaha. Variabel ini menunjukkan pengetahuan biaya para pelaku usaha dalam pengelolaan biaya dan pengorbanan usaha untuk memperoleh manfaat.

d. Pengetahuan biaya lingkungan. Variabel ini menunjukan pengetahuan pelaku usaha dalam mengelola biaya lingkungan serta pembebanan biaya lingkungan dalam biaya usaha.

e. Gaya pengeluaran individu. Variabel ini menunjukan perilaku pelaku usaha dalam melakukan pengeluaran dan menata keuangan usaha sehingga dapat mengetahui sikap pelaku usaha dalam mengelola keuangan.

Variabel b sampai $f$ diukur guna mengetahui tingkat kebutuhan pelaku bisnis. Untuk kebutuhan nilai "1" dikategorikan "sangat tidak penting", nilai "2" dikategorikan "tidak penting", nilai "3" dikategorikan "kurang penting", nilai "4" dikategorikan "biasa", nilai "5" dikategorikan "cukup penting", nilai "6" dikategorikan "penting", nilai "7 " dikategorikan "sangat penting".

\section{Menggunakan Kualitatif Deskriptif} dengan metode studi kasus yaitu metode yang dipergunakan dengan tujuan mempelajari sedalam-dalamnya salah satu gejala yang nyata dalam kehidupan bermasyarakat, dengan obyek adalah keadaan kelompok-kelompok dalam masyarakat, lembaga-lembaga masyarakat, maupun individu-individu dalam 
masyarakat (Sri W. dan Sutapa Mulyana, 2007).

\section{Hasil dan Pembahasan}

Dalam tabel karakteristik responden ditunjukan usia para pelaku bisnis yang kebanyakan diatas 50 tahun dan para pelaku bisnis tempe pun didominasi oleh perempuan dengan berpendidikan rata-rata SD dan maksimum SMA.

Tabel 1. Karakteristik Responden

\begin{tabular}{lcc}
\hline Variabel Penelitian & Jumlah & Persentase \\
\hline Jenis Kelamin: & & \\
Laki-laki & 29 & $96 \%$ \\
Perempuan & 1 & $4 \%$ \\
Usia: & & \\
Diatas 50 tahun & 20 & $96 \%$ \\
Dibawah 50 tahun & 10 & $4 \%$ \\
\hline
\end{tabular}

Tabel 2. Preferensi Kepentingan

\begin{tabular}{llrrrccc}
\hline No & Kepentingan & Sangat & Penting & Cukup & Kurang & Tidak & Sangat Tidak \\
& & Penting & & Penting & Penting & Penting & Penting \\
\hline 1. & Omzet & $43.33 \%$ & $56.67 \%$ & $0.00 \%$ & $0.00 \%$ & $0.00 \%$ & $0.00 \%$ \\
2. Laba & $53.33 \%$ & $43.33 \%$ & $3.33 \%$ & $0.00 \%$ & $3.33 \%$ & $0.00 \%$ \\
3. & Biaya Usaha Rendah & $0.00 \%$ & $0.00 \%$ & $73.33 \%$ & $10 \%$ & $16.67 \%$ & $0.00 \%$ \\
4. & Kualitas & $0.00 \%$ & $0.00 \%$ & $16.67 \%$ & $63.33 \%$ & 13.33 & $6.67 \%$ \\
5. & Produk/jasa Ramah & $0.00 \%$ & $0.00 \%$ & $6.67 \%$ & $13.33 \%$ & 66.6 & $6.67 \%$ \\
& Lingkungan & & & & & & \\
6. & Limbah & $3.33 \%$ & $0.00 \%$ & $0.00 \%$ & $10 \%$ & $0.00 \%$ & $86.67 \%$ \\
\hline
\end{tabular}

\section{Kepedulian Lingkungan}

Tabel 3 Kepedulian Lingkungan

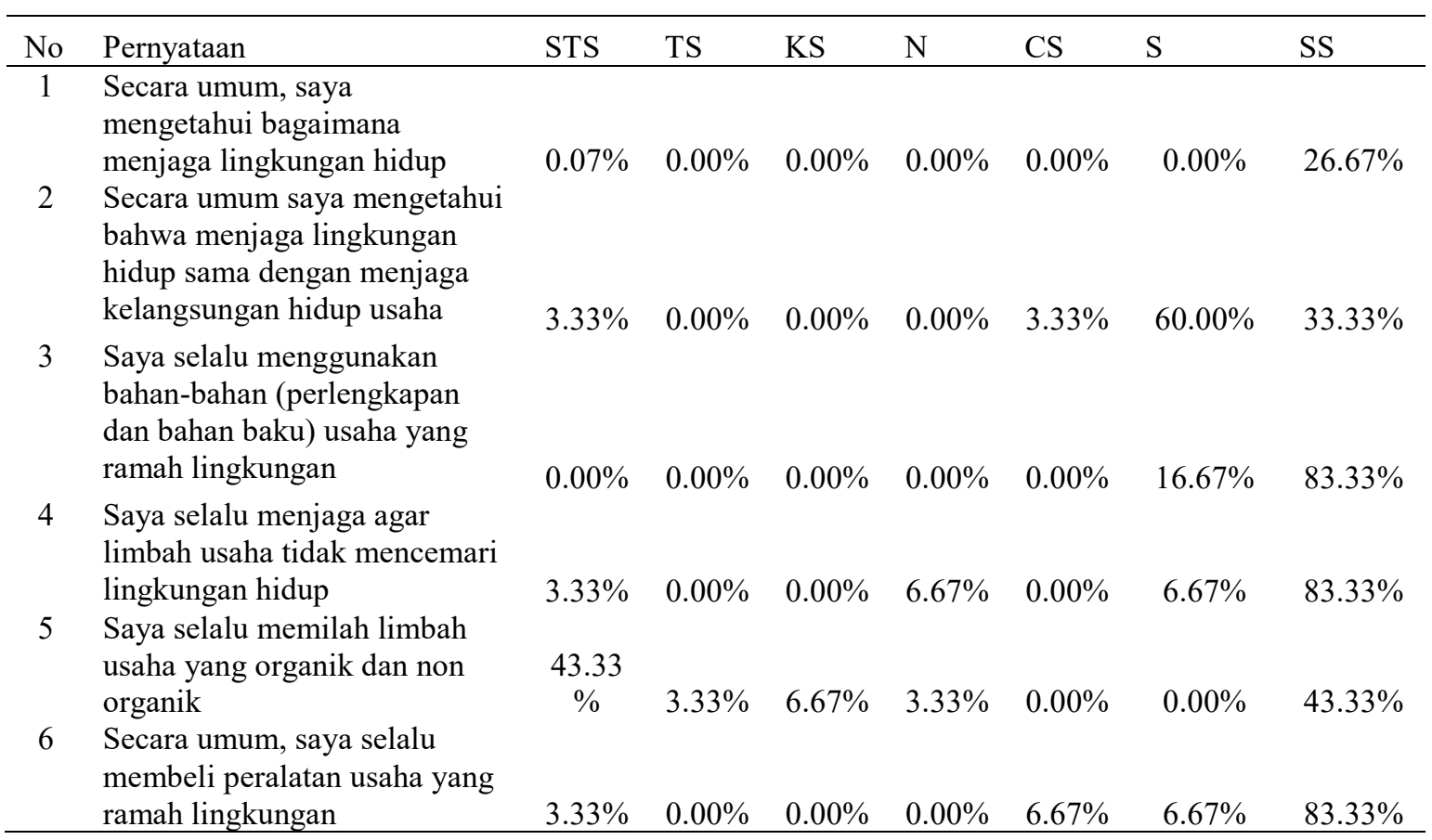


Tingkat kepedulian lingkungan para pelaku UKM tahu tempe yang berada di Kota Bandar Lampung berbeda antara satu dengan yang lainnya, hal ini dapat dilihat dari hasil jawaban atas kuesioner yang diberikan, dimana sebanyak $60 \%$ responden mengetahui bahwa menjaga lingkungan hidup sama dengan menjaga kelangsungan hidup usaha, kesadaran akan lingkungan yang baik menjadi modal dasar bagi pelaku usaha UKM dalam menjaga kelangsungan usahanya (sustainability). Berdasarkan hasil kuisioner juga diperoleh bahwa $83,33 \%$ pelaku UKM juga mengaku selalu menggunakan bahan-bahan (perlengkapan dan bahan baku) usaha yang ramah lingkungan hal ini karena para pelaku UKM menyadari bahwa produk yang mereka hasilkan merupakan produk pangan yang sangat ditentukan dari bahan baku yang terjaga keamanannya, selanjutnya ada sebanyak $83,33 \%$ pelaku UKM yang menjaga agar limbah tidak mencemari lingkungan hidup serta selalu membeli peralatan yang ramah akan lingkungan.

\section{Kesadaran Biaya Lingkungan}

Secara umum (sebanyak 70\%) pelaku usaha UKM mengetahui bahwa biaya lingkungan merupakan tanggung jawab usaha karena lingkungan merupakan hal yang mendapat dampak dari suatu kegiatan industri baik skala kecil maupun besar, oleh karenanya kesadaran atas dampak lingkungan sangat dibutuhkan dimiliki oleh para pelaku usaha. Namun banyak pelaku usaha UKM tahu tempe yang tidak memiliki pengetahuan yang baik mengenai biaya lingkungan yang diperlukan dalam usaha mereka. Limbah usaha selama ini hanya dibuang ke saluran air (parit) yang ada baik di depan maupun belakang kediaman yang sekaligus tempat usaha, ketidakpahaman pelaku UKM tahu tempe akan biaya lingkungan membuat selama ini mereka tidak memperhitungkan biaya tersebut dalam proses produksinya. Demikian pula dengan biaya yang terkait dengan limbah usaha, sebagian besar $(86,67 \%)$ pelaku usaha UKM tidak mengetahui biaya yang harus dikeluarkan untuk mengolah limbah. Kenaikan harga bahan baku dan bahan penolong untuk memproduksi tahu tempe membuat para pelaku usaha UKM tahu tempe tidak mempunyai ruang lagi untuk mengalokasikan biaya lingkungan sebagai beban usaha, oleh karenanya sebanyak 73,33\% pelaku usaha UKM sangat tidak setuju membebankan biaya lingkungan sebagai bagian dari beban usaha. 
Tabel 4 Kesadaran Biaya Lingkungan

\begin{tabular}{|c|c|c|c|c|c|c|c|c|}
\hline No & Pernyataan & STS & TS & KS & $\mathrm{N}$ & $\mathrm{CS}$ & $\mathrm{S}$ & SS \\
\hline 1 & $\begin{array}{l}\text { Secara umum, saya } \\
\text { mengetahui bahwa } \\
\text { biaya lingkungan } \\
\text { adalah tanggung } \\
\text { jawab usaha }\end{array}$ & $26.67 \%$ & $0.00 \%$ & $0.00 \%$ & $0.00 \%$ & $0.00 \%$ & $3.33 \%$ & $70.00 \%$ \\
\hline 2 & $\begin{array}{l}\text { Saya memiliki } \\
\text { pengetahuan yang } \\
\text { baik mengenai biaya } \\
\text { lingkungan yang } \\
\text { diperlukan dalam } \\
\text { usaha }\end{array}$ & $73.33 \%$ & $6.67 \%$ & $0.00 \%$ & $0.00 \%$ & $3.33 \%$ & $0.00 \%$ & $16.67 \%$ \\
\hline 3 & $\begin{array}{l}\text { Secara umum saya } \\
\text { mengetahui setiap } \\
\text { pengeluaran yang } \\
\text { dilakukan untuk biaya } \\
\text { lingkungan }\end{array}$ & $83.33 \%$ & $6.67 \%$ & $3.33 \%$ & $0.00 \%$ & $0.00 \%$ & $0.00 \%$ & $6.67 \%$ \\
\hline 4 & $\begin{array}{l}\text { Saya menggunakan } \\
\text { bahan-bahan usaha } \\
\text { ramah lingkungan }\end{array}$ & $73.33 \%$ & $6.67 \%$ & $3.33 \%$ & $0.00 \%$ & $3.33 \%$ & $0.00 \%$ & $13.33 \%$ \\
\hline 5 & $\begin{array}{l}\text { Saya mengetahui } \\
\text { biaya yang harus } \\
\text { dikeluarkan untuk } \\
\text { mengolah limbah } \\
\text { usaha }\end{array}$ & $86.67 \%$ & $13.33 \%$ & $0.00 \%$ & $0.00 \%$ & $0.00 \%$ & $0.00 \%$ & $0.00 \%$ \\
\hline 6 & $\begin{array}{l}\text { Saya membebankan } \\
\text { biaya lingkungan } \\
\text { sebagai bagian dari } \\
\text { beban usaha }\end{array}$ & $73.33 \%$ & $13.33 \%$ & $3.33 \%$ & $0.00 \%$ & $0.00 \%$ & $0.00 \%$ & $10.00 \%$ \\
\hline
\end{tabular}

\section{Pengetahuan Biaya}

Biaya merupakan pengorbanan sumbersumber ekonomi yang diukur dalam satuan uang, yang telah terjadi atau yang mungkin akan terjadi untuk tujuan tertentu. Pelaku usaha harus mampu mengidentifikasikan biaya-biaya yang muncul dalam proses produksinya agar dapat dengan tepat menghitung profitnya. Secara umum pelaku usaha UKM mengetahui bagaimana mengelola biaya usaha, kemampuan untuk mengelola tersebut diperoleh secara otodidak dan merupakan perhi-tungan biaya yang sederhana. Pelaku usaha hanya mengakumulasikan semua biaya bahan baku dan penolong dalam proses produksi sebagai beban usaha. Dalam menghitung biaya usaha pelaku usaha UKM telah memisahkan antara biaya usaha dan pengeluaran pribadi. Pemahaman untuk memisahkan dana pribadi dan dana usaha sangat penting bagi pelaku usaha, hal ini diperlukan untuk lebih mengetahui berapa total biaya usaha serta profit usaha yang dijalani. 
Tabel 5 Pengetahuan Biaya

\begin{tabular}{|c|c|c|c|c|c|c|c|c|}
\hline No & Pernyataan & STS & TS & $\mathrm{KS}$ & $\mathrm{N}$ & $\mathrm{CS}$ & $\mathrm{S}$ & SS \\
\hline 1 & $\begin{array}{l}\text { Secara umum, saya } \\
\text { mengetahui bagaimana } \\
\text { mengelola biaya usaha }\end{array}$ & $23.33 \%$ & $0.00 \%$ & $0.00 \%$ & $0.00 \%$ & $0.00 \%$ & $3.33 \%$ & $73.33 \%$ \\
\hline 2 & $\begin{array}{l}\text { Saya selalu mengukur kinerja } \\
\text { usaha saya dalam profit } \\
\text { (keuntungan) }\end{array}$ & $26.67 \%$ & $0.00 \%$ & $0.00 \%$ & $3.33 \%$ & $3.33 \%$ & $3.33 \%$ & $63.33 \%$ \\
\hline 3 & $\begin{array}{l}\text { Saya mengetahui bagaimana } \\
\text { mengelola biaya usaha }\end{array}$ & $20.00 \%$ & $0.00 \%$ & $6.67 \%$ & $6.67 \%$ & $0.00 \%$ & $6.67 \%$ & $60.00 \%$ \\
\hline \multirow[t]{2}{*}{4} & Saya mengetahui komponen- & & & & & & & \\
\hline & komponen biaya usaha & $16.67 \%$ & $3.33 \%$ & $3.33 \%$ & $6.67 \%$ & $0.00 \%$ & $0.00 \%$ & $70.00 \%$ \\
\hline 5 & $\begin{array}{l}\text { Saya memiliki pengalaman } \\
\text { yang cukup untuk mengelola } \\
\text { biaya usaha }\end{array}$ & $26.67 \%$ & $3.33 \%$ & $0.00 \%$ & $3.33 \%$ & $0.00 \%$ & $3.33 \%$ & $63.33 \%$ \\
\hline 6 & $\begin{array}{l}\text { Saya memilahkan pengeluaran } \\
\text { usaha yang dilakukan dengan } \\
\text { pengeluaran pribadi }\end{array}$ & $10.00 \%$ & $0.00 \%$ & $0.00 \%$ & $3.33 \%$ & $6.67 \%$ & $13.33 \%$ & $66.67 \%$ \\
\hline \multirow[t]{2}{*}{7} & $\begin{array}{l}\text { Saya mengetahui bagaimana } \\
\text { membebankan biaya usaha } \\
\text { dalam perhitungan harga } \\
\text { produk/jasa maupun }\end{array}$ & & & & & & & \\
\hline & perhitungan profit/keuntungan & $10.00 \%$ & $0.00 \%$ & $0.00 \%$ & $0.00 \%$ & $0.00 \%$ & $6.67 \%$ & $83.33 \%$ \\
\hline
\end{tabular}

\section{Pengetahuan Biaya Lingkungan}

Tabel 6 Pengetahuan Biaya Lingkungan

\begin{tabular}{|c|c|c|c|c|c|c|c|c|}
\hline No & Pernyataan & STS & $\mathrm{TS}$ & $\mathrm{KS}$ & $\mathrm{N}$ & $\mathrm{CS}$ & $\mathrm{S}$ & $\mathrm{SS}$ \\
\hline \multirow[t]{2}{*}{1} & $\begin{array}{l}\text { Secara umum, saya mengetahui } \\
\text { bagaimana mengelola biaya }\end{array}$ & & & & & & & \\
\hline & lingkungan & $96.67 \%$ & $0.00 \%$ & $0.00 \%$ & $0.00 \%$ & $0.00 \%$ & $0.00 \%$ & $3.33 \%$ \\
\hline \multirow[t]{2}{*}{2} & $\begin{array}{l}\text { saya memiliki pengalaman yang } \\
\text { cukup untuk mengelola biaya }\end{array}$ & & & & & & & \\
\hline & lingkungan & $93.33 \%$ & $6.67 \%$ & $0.00 \%$ & $0.00 \%$ & $0.00 \%$ & $0.00 \%$ & $0.00 \%$ \\
\hline \multirow[t]{2}{*}{3} & $\begin{array}{l}\text { Secara umum saya memiliki } \\
\text { pengetahuan mengenai biaya }\end{array}$ & & & & & & & \\
\hline & lingkungan & $83.33 \%$ & $13.33 \%$ & $3.33 \%$ & $0.00 \%$ & $0.00 \%$ & $0.00 \%$ & $0.00 \%$ \\
\hline \multirow[t]{2}{*}{4} & Saya mengetahui komponen- & & & & & & & \\
\hline & komponen biaya lingkungan & $70.00 \%$ & $26.67 \%$ & $0.00 \%$ & $0.00 \%$ & $0.00 \%$ & $0.00 \%$ & $3.33 \%$ \\
\hline 5 & $\begin{array}{l}\text { Saya mengetahui bagaimana } \\
\text { membebankan biaya lingkungan } \\
\text { dalam biaya usaha }\end{array}$ & $70.00 \%$ & $23.33 \%$ & $0.00 \%$ & $0.00 \%$ & $0.00 \%$ & $0.00 \%$ & $6.67 \%$ \\
\hline
\end{tabular}

Biaya lingkungan yang terjadi dalam perusahaan merupakan salah satu biaya overhead yang sulit sekali untuk diidentifikasikan secara langsung dikarenakan biaya-biaya tersebut seringkali tersembunyi dalam pusat biaya dan tidak ada bukti pencatatan atau pelaporan yang jelas terkait dengan biaya lingkungan (Ikhsan, 2008).
Ketidakpahaman pelaku UKM tentang bagaimana mengelola biaya lingkungan membuat mereka tidak menjadikan biaya lingkungan sebagai salah satu komponen biaya usaha. Hal ini dapat disebabkan karena kurangnya pengalaman mereka dalam mengelola biaya lingkungan. Pengetahuan yang minim dari pelaku UKM atas biaya 
lingkungan menyebabkan mereka tidak

mengetahui komponen-komponen biaya

lingkungan.

\section{Gaya Pengeluaran Individu}

Pemahaman pelaku usaha dalam memisahkan antara pengeluaran pribadi dan usaha menjadi hal penting, karena hal tersebut akan berpengaruh terhadap gaya pengeluaran individunya. Berdasarkan hasil penelitian yang dilakukan pada pelaku usaha UKM tahu tempe di kota Bandar Lampung diperoleh bahwa para pelaku UKM merasa perlu untuk mengecek ketersediaan uang ketika akan membeli sesuatu, dan selalu berhati-hati dalam melakukan pengeluaran pribadi dibandingkan pengeluaran usaha. Berdasarkan hasil penelitian juga diperolah bahwa semua pelaku UKM ketika melakukan pengeluaran usaha selalu merasa seperti melakukan pengeluaran pribadi.

Tabel 7 Gaya Pengeluaran Individu

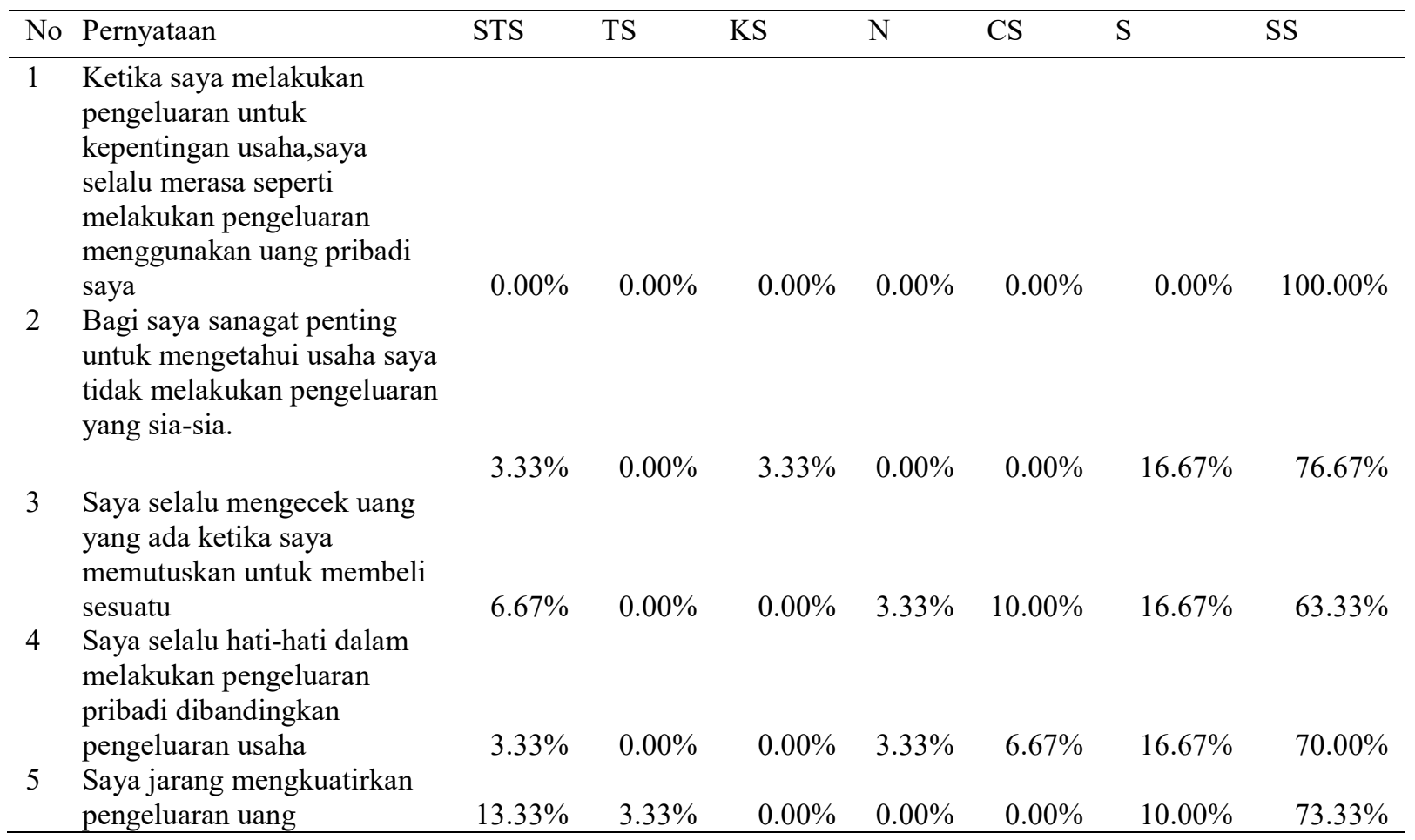

\section{Kesimpulan}

Berdasarkan hasil penelitian diperoleh bahwa pemahaman para pelaku UKM tahu tempe di kota Bandar Lampung masih kurang hal ini karena preferensi kepentingan para pelaku UKM tahu tempe masih terfokus atas laba usaha belum pada kualitas produk dan kualitas lingkungan. Belum adanya kesadaran akan dampak lingkungan yang dapat mempengaruhi keberlangsungan usahanya menjadi faktor yang menyebakan rendahnya pemahaman tersebut. Dari sisi pengetahuan atas biaya lingkungan para pelaku UKM tahu tempe di Kota Bandar Lampung juga masih kurang hal ini terjadi karena belum mampunya para pelaku usaha untuk mengidentifikasikan 
apa yang menjadi komponen-komponen biaya lingkungan juga menjdi faktor yang menyebabkan rendahnya pemahaman para pelaku UKM tahu tempe tersebut. Masih kurangnya pemahaman dan penge-tahuan para pelaku UKM tahu tempe tersebut salah satunya karena kurangnya sosialisasi dan keterbatasan waktu yang dimliki para pelaku usaha untuk dapat mempelajari tentang konsep dari biaya lingkungan dan green accounting.

Penelitian ini masih belum dapat menggambarkan keseluruhan populasi dari pelaku UKM tahu tempe karena sampel yang dapat diperoleh masih rendah, sehingga untuk peneliti selanjutnya dapat menambah jumlah responden dan menambah kelompok UKM yang menjadi sample penelitian. Selain itu bagi para pelaku UKM tahu tempe seharusnya dapat meningkatkan pemahaman dan pengetahuannya atas biaya lingkungan, karena hal tersebut sangat penting tidak hanya untuk kelangsungan lingkungan namun juga untuk kelangsungan usaha mereka sendiri, peningkatan pemahaman tersebut tentunya harus didukung oleh semua pihak antara lain dari pemerintah dari unsur akademisi maupun masyarakat pada umumnya.

\section{Daftar Pustaka}

\section{Jurnal}

Arizona, I Putu Edy dan I Wayan Suarjana. 2017. Kepedulian Dan Pengetahuan Pelaku Bisnis Mengenai Green Accounting. Jurnal Riset Akuntansi JUARA. Vol.7 No.2, September 2017.

Kartikasari, Lisa. 2012. Niat Akuntan dan Akuntansi Lingkungan. Universitas Islam Sultan Agung. vol: | issue : | 2012.
Martusa, Riki. 2009. Peranan Environmental Accounting terhadap Global Warming. Jurnal Akuntansi Vol.1 No 2 November 2009: 164-179. Bandung.

Musyarofah, Siti. 2013. Analisis Penerapan Green Accounting di Kota Semarang. Fakultas Ekonomi Universitas Negeri Semarang. ISSN 2252-6765 http://journal.unnes.ac.id/sju/index.php/a aj.

Fasua, Kayode Olushola, 2011, "Environmental Accounting: Concept and Principles" Certified National Accountant Volume 19 Number 2 April - June, 2011.

\section{Buku}

Ikhsan, Arfan. 2008. Akuntansi Lingkungan dan Pengungkapannya. Yogyakarta: Graha Ilmu.

Sri. Winarti dan Sutapa Mulya. 2007. Sosiologi. Surakarta: UNS Press.

PRIMKOPTI. 2016. Data Primer Koperasi Tahu Tempe Indonesia 2016.

\section{Artikel dalam Prosiding}

Ja'far S, Muhammad dan Lisa Kartikasari. 2012. Carbon Accounting: Implikasi Strategis Perekayasaan Akuntansi Manajemen. SNA XII Palembang. vol: | issue : | 2009

Kwarto, F. 2010. Synchronization Of Green Accounting With Company Managerial Accounting; A Corporate Financial Department Perspective.

Pramanik, A.K., Shil, N.K., dan Das, Bhagban. 2008. Environmental Accounting and Reporting with Spesial Reference to India. MPRA Paper No. 7712. India

Wiryani, Erry. 2007. "Analisis Kandungan Limbah Cair Pabrik Tempe" Universitas Diponegoro. Semarang. BIOMA . ISSN 1410-8801. 


\section{Skripsi, Tesis, Disertasi}

Christyawa, Thomas T. 2014. Kepedulian Dan Pengetahuan Pelaku Usaha Mengenai Green Accounting (Studi Kasus Pada Usaha Tahu Di Kota Salatiga). Skripsi Mahasiswa Fakultas Ekonomika Dan Bisnis Universitas Kristen Satya Wacana Salatiga.
Purwaningsih, I. 2008. Pengolahan Limbah Cair Industri Batik Cv. Batik Indah Raradjonggrang Yogyakarta Dengan Metode Elektrokoagulasi Ditinjau Dari Parameter Chemical Oxygen Demand (COD) dan Warna, Skripsi Untuk Memperoleh Gelar Sarjana Teknik Lingkungan, UII, Yogyakarta. 